\title{
Pseudoaneurysm of the ascending aorta in a patient with ascending aorta aneurysm and our surgical procedure
}

\author{
K Ergunes*', L Yilik, I Peker, N Karahan, Y Besir, A Gurbuz \\ From 23rd World Congress of the World Society of Cardio-Thoracic Surgeons \\ Split, Croatia. 12-15 September 2013
}

\section{Background}

The wall of aneurysm in aortic aneurysm is composed of the normal histological component of aorta. Pseudoaneurysm represents a rupture which does not contain the normal histological component of aorta. We described a case of pseudoaneurysm of the ascending aorta in patient with ascending aorta aneurysm.

\section{Methods}

We presented the case of 58-year-old man. He admitted to our hospital with for chest pain. Chest computed tomography showed that the ascending aorta was $55 \mathrm{~mm}$ and a pseudoaneurysm was observed about $2 \mathrm{~cm}$ of noncoronary cusp. Arterial access to establish cardiopulmonary bypass performed via the right common femoral artery. Venous cannulation was performed with right atrial double-stage cannula. Myocardial protection was achieved with a combination antegradely and retrogradely of isothermic blood cardioplegia.

\section{Results}

Proximal ascending aorta including pseudoaneurysm was resected from about $1.5 \mathrm{~cm}$ of coroner cusps and distal ascendin aorta was resected about $2 \mathrm{~cm}$ proximal of truncus brachiocephalicus. A $28 \mathrm{~mm}$ tube graft was replaced between proximal and distal ascending aorta. The operation and recovery was uneventful.

* Correspondence: kazimergunes@yahoo.com

Izmir Katip Celebi University Ataturk Training and Research Hospital,

Department of Cardiovascular Surgery, Izmir, Turkey

\section{Conclusions}

This unusual presentation of pseudoaneurysm in patient with ascending aort aneurysm can help to manage similar cases.

Published: 11 September 2013

doi:10.1186/1749-8090-8-S1-P3

Cite this article as: Ergunes et al:. Pseudoaneurysm of the ascending aorta in a patient with ascending aorta aneurysm and our surgical procedure. Journal of Cardiothoracic Surgery 2013 8(Suppl 1):P3.
Submit your next manuscript to BioMed Central and take full advantage of:

- Convenient online submission

- Thorough peer review

- No space constraints or color figure charges

- Immediate publication on acceptance

- Inclusion in PubMed, CAS, Scopus and Google Scholar

- Research which is freely available for redistribution
Ciomed Central 